\title{
Developing Tax Policy in a Complex and Changing World
}

\author{
Simon James and Alison Edwards* \\ School of Business and Economics, University of Exeter, \\ Streatham Court, Rennes Drive, Exeter EX4 4PU, UK \\ (email:SRJames@ex.ac.uk)
}

\begin{abstract}
This paper examines issues affecting the formulation of tax policy through to the development of actual proposals by tax policy-makers. This is done taking account of the possibility that too narrow an approach to this process can produce misleading conclusions and that proposals for tax reform may be inappropriate when the wider context of the tax system as a whole and the environment in which it has to operate are considered. Two issues are used to illustrate this situation - tax compliance and tax simplification. The paper concludes that in developing tax policy it is important to ensure that the wider context is taken into account and it also outlines a practical approach to achieve this aim.
\end{abstract}

\section{INTRODUCTION}

Developing tax policy is a complex process yet much of the research into taxation is undertaken and many reforms are proposed on a relatively narrow basis. Taking account of the wider context - that is other aspects of the tax system, government expenditure programs, noneconomic as well as economic variables and the economic, social and political environment - might affect the conclusions drawn by some researchers and changes to the tax systems proposed by policy-makers. This is discussed here in terms of the theory of the second best and optimal taxation. To illustrate this issue, the paper goes on to examine two particular areas - tax compliance and tax simplification - and the importance of examining these in a wider context when drawing conclusions about tax policy.

Tax systems are used to achieve a range of aims and objectives and to do so in a complex and changing environment. It is in the interests of governments and, of course, the people they represent, that these aims and objectives are achieved efficiently and effectively. The two areas discussed here - tax compliance and tax simplicity - provide examples of important issues

The authors are very grateful for research funding from the Economic and Social Research Council (Award number RES-000-23-1595 'Optimum Tax Compliance Costs and Tax Simplification') to anonymous referees for very helpful recommendations and to Dr Ian Wallschutzky, those attending the presentation at the Conference of the Society for the Advancement of Behavioral Economics at New York University in May 2007 and members of the staff research seminar at the University of Sydney for helpful comments on earlier versions of this paper. 
in taxation which are perhaps too often examined in relative isolation from other factors. Tax systems exist not only to raise revenue but are also used in support of a range of public policy objectives in different circumstances and these need to be taken into account in developing policy with respect to all aspects such as compliance and tax simplification. Even some otherwise excellent research studies do not always take sufficient account of the relationships between different aspects of tax systems and the environments in which they have to operate when drawing conclusions about improvements in taxation. For example, quite correctly, Sandford, Godwin and Hardwick (1989, p. 203) pointed out that administration and compliance costs were linked and should not be considered in isolation. They went on to conclude that:

'Perhaps the best that can be done is to suggest that the objective might be phrased in terms of minimizing operating costs in obtaining a given revenue from a given tax structure'.

Clearly Sandford et al. appreciate that there may be a trade-off between operating costs and particular tax structures, but they do not examine the relationships between these costs and the different aspects of a tax system. Similarly commentators on tax simplification often do not take sufficient account of the importance of other matters. For instance, an early paper entitled 'Tax Simplification' in the Accounting Review ended:

'The results will largely be measured by the number of pages remaining in the Code' (Bachrach 1945, p. 103).

That would certainly be a simple measure of tax reform with respect to tax simplification but would probably not be the most useful and would certainly not be a good measure of improvement of the tax system as a whole.

An approach that takes a wider perspective - including the range of government policies that are sometimes at least partly implemented through the tax system - may result in conclusions that could be quite different. For instance, tax compliance is often discussed in terms of minimizing compliance costs. However if, for example, the purpose of a particular tax is to discourage a certain activity such as the use of alcohol or tobacco or even possibly the consumption of fatty foods on health grounds (O'Donoghue and Rabin 2006), then the conclusion may no longer be that compliance costs, or operating costs in total, should be minimized - indeed higher compliance costs might help achieve the objective.

Of course, tax research cannot be expected to take full account of every relevant aspect all the time. Researchers often need to develop specialist knowledge rather than wider expertise and research in depth might have to be limited in scope. Therefore, an important question is how far research should include the wider context in developing conclusions. In a preliminary survey by the present authors of the research on compliance and simplification, it seems that much of the work could make a stronger contribution if it were linked to wider issues.

To indicate the importance of taking account of related matters in developing tax research and policy proposals, Section II discusses contributions from Economics - the general theory of the second best and optimal taxation - which give an indication of the complexity of the matters involved. Section III turns to compliance and the importance not only of economic variables but also other variables that are more frequently the subject of study in disciplines such as psychology and sociology. Section IV discusses tax simplification as another example 
where any successful reform is almost certain to be multi-dimensional. Section $\mathrm{V}$ is then concerned with developing a systematic and practical way to formulate policy proposals taking account of all relevant factors on a continuing basis and finally Section VI goes on to draw some conclusions. The paper turns first to contributions from Economics.

\section{CONTRIBUTIONS FROM ECONOMIC ANALYSIS}

Economic analysis has a great deal to offer in understanding the need for a more comprehensive approach to tax research and reform than always takes place currently. Two particularly useful areas are the general theory of the second best and the theory of optimal taxation. Public choice theory also has much to offer but the implications of that analysis will be left to a later paper.

\section{The General Theory of the Second Best}

One of the themes of a wider approach to the issues of compliance and simplification is the interdependence between different economic, as well as political and social, variables and realities. One important insight, probably not very well known outside mainstream economics, is the theory of the second best. This relates to the fact that the variables in an economic system interact so that changing one part will have effects on other variables that are not even directly involved in the initial change. A limited analysis may fail to anticipate such changes, which could offset the original intended improvement. This can mean that a reform designed to achieve an economic improvement, far from actually doing so, might even make things worse.

This does not seem to be consistent with normal intuition but it might be illustrated with a simple example where two economic distortions are offsetting each other. Suppose a monopolist - a single seller of some good or service - might wish to exploit its market power and push the price up but has only one customer who has the market power to keep the price down and the result might be something like the optimum price. However, to remove either the economic power of the monopolist or its customer without removing both could result in the market price moving away from the optimal position. As a tax example, it is often suggested that taxes should be imposed to counteract external effects - say pollution - or some other environmental concern. This may be true if the external effect causes the price to give the wrong economic signal about the full cost of the output including the external costs. The tax could be used to represent the social cost in the market which would then be guided in the right direction. This is not the only possibility though. It may be that existing distortions have already pushed the price in this direction and, if tax policy makers have not considered all aspects of the change before implementing it, the resulting tax might move the price further rather than closer to the optimum position.

More generally the theory of the second best states that it

'is not true that a situation in which more, but not all, of the optimum conditions are fulfilled is necessarily, or is even likely to be, superior to a situation in which fewer are fulfilled' (Lipsey and Lancaster 1956, p. 12).

Indeed the general theory of the second best holds that if one of the Paretian optima cannot be achieved then a second best optimum can be reached by departing from all the other optimum 
conditions. Furthermore, nothing can be said in general about the direction or the magnitude of the secondary deviations from optimum conditions made necessary by the inability to achieve the original optimum condition. Lipsey and Lancaster actually illustrate this with a tax example. They suppose that a tax is imposed on one good only and the revenue raised is returned as a gift to the purchasers so the only result is to distort relative prices. Given this distortion, the only general thing that can be said is that a second best optimum could only be achieved by a system of taxes on other goods and services, some of which may be more than, some less than, the original tax and in some cases a subsidy might be required.

As already indicated, the tax system is not an independent entity and imperfections in the tax system may have implications for the pattern of public expenditure. For example, Balestrino and Galmarini (2003) argued that imperfect income tax compliance implies it is desirable that the supply of public goods should be distorted downwards. At a more detailed level an infinite amount of such analysis is possible. For instance, West and Williams (2007) estimate the parameters required to calculate the optimal second-best gasoline tax.

The implication of 'second best' analysis is that the failure to consider a much wider range of factors than is currently the norm might mean that an 'improvement' in tax compliance or simplification does not lead to an overall improvement at all. When the wider context is included, the overall disadvantages may be greater than the more obvious benefits of the initial change. The literature on optimal taxation adds further insights and is therefore also described briefly next.

\section{Optimal Taxation}

The work on optimal taxation is relevant here because the literature is concerned with tax structures that take account of both the requirements of economic efficiency and the need to be fair between one taxpayer and another. It is concerned with questions such as whether income or commodity taxes should be used and how tax rates should vary across commodities. The equity dimension relates to the question of how progressive the tax system should be. To some extent, of course, there is a trade-off between the two criteria of efficiency and equity. A tax system that is economically efficient may not be considered fair and vice versa and the purpose of much of the optimal taxation literature is to find the best balance between the two. Having said that, it is not always easy to model what is considered to be fair and there have been difficulties in incorporating important variables.

One of the earliest and most famous contributions was Ramsey's (1927). He concluded that uniform commodity taxes were rarely optimal, though it might be noted that the analysis abstracted from the costs of operating different tax rates. There is now a considerable literature on optimal taxation though Broome's (1975) parody suggests that it should not always be taken literally. Frey (1976, p. 32) pointed out that optimal taxation will only be introduced if it is acceptable within the political-economic process. Feldstein (1977) criticized the literature for concentrating too much on the features of the optimum and too little on the process of attaining it. An accessible summary is provided by Heady (1993) who also raised the specific question of the contribution optimal taxation could make to practical tax policy. Although that literature clearly offers some important insights, it cannot help in all areas of tax policy. 
Indeed the difficulty of applying much of the work in optimal taxation to policy issues is a constant theme. Alm (1996) suggested that previous attempts to derive an 'optimal tax system' were largely irrelevant to practical tax design since they ignored a range of considerations involving fiscal and social institutions. He argued that many of the relevant institutional features could be included in an optimal tax framework but acknowledged that it would never be able to incorporate all of the 'incredible complexity' that must be considered in the design and reform of tax systems.

Nevertheless research relating to optimal taxation continues to develop and often in the right direction by including additional variables from the wider context. Gradstein (1999) examined political mechanisms that ensure efficiency enhancing restraints on taxation. In the context of the present paper, the discussion of optimal taxation and evasion is particularly relevant because, as with other areas, the analysis results in important insights but not precise policy prescriptions. Cremer and Gahvari (1994) suggest that the optimum marginal tax rate is lower in the presence of tax evasion but this depends on their particular assumptions. An increase in tax rates may improve economic efficiency as it might cause some labor to move into the illegal labor market which may be less economically distorted than the legitimate one. However, as Sandmo (2005, p. 658) points out, there are some serious implications in viewing 'anti-social behavior' as a social gain in this way. There is the theoretical but rather crude insight that increasing the probability of detection by increasing the frequency of audits and penalties for evasion are substitutes. Concern about minimizing compliance costs might indicate a preference for the latter. However, shifting costs from the public to the private sector is no guarantee of a net gain and on equity grounds, if no other, that approach may lead to unacceptably high penalties for the few who are caught for crimes committed by many individuals who escape unscathed. In any case the decision to evade may well be heavily influenced by behavioral rather than economic factors narrowly defined (James et al. 2001).

The recent study by O'Donoghue and Rabin (2006) used the optimal taxation framework to examine 'sin taxes' - such as those on unhealthy foods that people might consume more than they should because they lack self-control or some other problem. The existence of merit goods or merit bads where the government and individuals have different ideas about individuals' optimal consumption was raised by Musgrave (1959) and has been discussed ever since. In a sense an individual's consumption that does not take full account of future harm might be thought of as an internal externality with respect to that individual's future health - or an 'internality' as Herrnstein et al. (1993) put it. O'Donoghue and Rabin show that introducing taxes on unhealthy items and returning the proceeds to the taxpayers can increase economic welfare, but such a conclusion can be reached without using optimal taxation analysis. The authors also acknowledge that the analysis has numerous limitations. This is generally in line with the nature of the optimal taxation approach and so the policy implications are also limited.

The optimal taxation approach once again reinforces the point that it is a difficult and complex process to develop changes to the tax system where the advantages outweigh the disadvantages. Yet it is also clear that giving the wider context less attention than it deserves is not the way to proceed. This can be illustrated by the issue of tax compliance examined in the following section. 


\section{TAX COMPLIANCE}

On the basis of a thorough analysis of the extensive research into tax compliance in Australia, Turner (1996, p. 5) found:

'The tendency has been to define the scope of study too narrowly with the result that researchers have lost sight of the fact that this is merely one small facet of the citizen's relationship with the state'.

And

'The view that incremental costs of complying with the tax laws can be studied without reference to the total system costs is unnecessarily narrow and unlikely to help in understanding the subject. There has been an excessive emphasis on exploratory research'.

There is also evidence of similar limitations to tax compliance research in other countries. There is now a huge body of research on tax compliance (see, for example, Jackson and Milliron 1986, Fischer, Wartick and Mark 1992, Richardson and Sawyer 2001, Ahmed et al. 2003 and Kirchler 2007). In particular, there has been a constant stream of studies estimating actual compliance costs but often without considering compliance costs as part of wider tax policy. For instance such studies often imply that all would be well if only compliance costs were low and progressive rather than high and regressive. As indicated above, whether this is correct or not depends on a range of factors and if, for example, a tax is being used to discourage a particular form of behavior then higher rather than lower compliance costs might even be desirable. With respect to the issue of progressivity, it does not follow that each part of the tax system has to be equally progressive, or indeed even that every part of it individually has to be progressive at all. It certainly does not require that compliance costs always have to be progressive. A further dimension is the literature focusing on the 'tax gap' which represents the difference between the actual revenue collected and the amount that would be collected if there were 100 per cent compliance. In isolation this aspect might also lead to inappropriate results - for example an oppressive enforcement policy might discourage enterprise and reduce the tax gap partly by reducing the amount of income there is to tax (James et al. 2001).

It may be, of course, that some research is deliberately focused on only a small aspect - such as a particular estimate of compliance costs in a specific context - to be concerned about such wider issues. An example is the study by Shekidele (2001) of excise duties in Tanzania. Nevertheless this study includes some discussion of the background and perhaps it should have considered the wider context as well since it might affect the conclusions. Sometimes researchers are aware of trade-offs between different parts of the tax system but do not seem to follow this through to its logical conclusion. For example, Serra (2003, p. 374) states that the goal of the tax administration should be to minimize collection costs for a given tax structure and tax administration budget and that joint minimization of tax evasion and costs of compliance can be used as a proxy for minimizing collection costs which would be very difficult to observe directly. He argues that the compliance rate could serve as the effectiveness indicator for the compliance maximization objective. Serra's argument for maximizing tax compliance is that minimizing tax collection costs should be a goal of the tax administration and that tax collection 
costs generally fall when there is a higher rate of compliance (p. 375). He is aware of the tradeoffs of different aspects of the tax system as he goes on to say that higher compliance means the government could have either lower tax rates or administrative costs and the optimum response is likely to be a combination of the two. Nevertheless he adds that the precise relationship between compliance and collection costs depends on the way compliance maximization is achieved ( $\mathrm{p}$. 376). Serra acknowledges in the conclusion that the compliance rate is not appropriate as an indicator of the effectiveness of tax administration since tax compliance is influenced by factors other than the tax administration - such as high economic growth - and because tax enforcement could increase compliance costs. Serra therefore concludes that a second objective for the tax administration should be 'to minimize compliance costs'.

One indication that this approach may be too narrow is the increasing contribution of researchers using a behavioral approach to extend such analyses. This approach is not so concerned with a mechanistic compliance cost minimization policy or concentrating on purely economic factors such as the frequency and level of auditing and penalties for those caught misbehaving. Instead the behavioral approach tries to take a wider view that might not only enable improvements to be made in compliance policy but also for there to be co-ordination with other government aims, objects and public expenditure programs.

There are many contributions from different disciplines that suggest there is a range of other factors that might influence taxpayers' behavior. For instance, work in sociology has identified a number of relevant variables such as social support, social influence, attitudes and certain background factors such as age, gender, race and culture. Psychology reinforces this approach and has even created its own branch of 'fiscal psychology' (Schmölders 1959, Lewis 1982). The contribution of economic psychology, examined for example by Cullis and Lewis (1997) and Kirchler (2007), indicates that attitudes towards the State and revenue authorities, fiscal consciousness, morals, perceptions of equity and values are important factors in determining compliance decisions. The roles of individuals in society and accepted norms of behavior have also been shown to have a strong influence (Wenzel 2004a, 2004b and 2005). These variables may be complex and also interact with each other - for instance Braithwaite et al. (2003) explored such factors as the perception of justice and how social norms and laws can undermine each other.

The main theme of this wider approach to tax compliance is that individuals are not simply selfish individuals who are only concerned with maximizing their own immediate personal utility (though this might be partly true) but that they also interact with other human beings in ways that depend on different attitudes, beliefs, norms and rules. It also means that taxpayers as social beings can in many circumstances be expected to act as responsible citizens. Therefore normally they should conform to reasonable obligations of the tax system without the need for heavy handed enforcement activity - which might even be counter productive. For example, both Schmölders (1970) and Strümpel (1969) reported that the German system was very rigid in its assessment procedures which led to an effective but expensive and confrontational system. The result

'of the relatively coercive tax-enforcement techniques is the high degree of alienation from the state...[which] negatively influences the willingness to cooperate' (Strümpel 1969, p. 29). 
In contrast it was claimed that the 'British tax system treats businessmen and professional persons with great caution' and so avoids friction (ibid.) There is other evidence that the UK tax authorities have had a traditionally deferential approach towards income taxpayers (see for example, Sabine 1965) but also that there has been some movement away from that stance in recent years. It was suggested that there was a third approach - in the

'Romanic countries, the discrepancy between law and reality...is the main driving force behind the vicious circle of noncompliance, perceived inequity and refusal to cooperate' (Strümpel 1969, p. 32).

Such matters must therefore be taken into account in considering compliance policy. There are many detailed contributions to a wider approach to compliance - including some by economists. For example, non-maximizing behavior has been examined by Spicer (1986), the importance of equity and fairness has been a frequent theme (for example, by Bordignon 1993 and Cowell 1992) and social norms have also been included in the analysis by some authors such as Alm, McClelland and Schulz (1999) and Chang and Lai (2004). In fact a very substantial part of the tax compliance literature adopts an approach wider in one way or another than the narrower economic approach. This can be illustrated by an analysis by the present authors of the annotated bibliography relating to voluntary tax compliance compiled by Ahmed et al. (2003) of the Centre for Tax System Integrity (CTSI) at the Australian National University. The bibliography was restricted to contributions that are concerned with tax compliance or ideas relating to compliance published since 1960 though a few earlier publications were included if they were particularly relevant. The bibliography is divided into 10 sections and the analysis covered the first eight - section 9 consisted of CTSI working papers and section 10 edited collections. Of the 467 contributions considered, 114 could be said to follow a relatively narrow economic approach but a further 229 were concerned with wider issues. Another 124 were concerned with other related matters such as the cash economy, regulatory compliance in general rather than tax compliance in particular and justice. In a bibliography of contributions on tax compliance currently being compiled by the present authors, 785 entries had been included at the time of writing, the majority of which are concerned with issues beyond the relatively narrow economic approach.

Of course, including variables in addition to purely economic ones greatly increases the complexity of the issue. There have been comprehensive studies examining different variables that influence tax compliance. Jackson and Milliron (1986) focused on 14 variables that influenced noncompliance - age, gender, education, income level, type or nature of income and whether tax is withheld at source, occupation, peer influence, ethics, fairness, complexity, revenue authority contact, probability of detection, sanctions, tax rates, and 'other variables'. Richardson and Sawyer (2001) reviewed 43 further compliance studies and synthesized the results for each of the 14 variables examined in the earlier Jackson and Milliron study. They found that although there had been progress in terms of increased certainty of the effect on noncompliance for two of the variables (contact with the revenue authority and sanctions) or certainty had been maintained (tax withheld at source, ethics and the probability of detection), most of the ambiguities in the original study remained in the case of many of the other variables (age, gender, education, income level, occupation, fairness, complexity and tax rates) or 
certainty had actually decreased (peer influence and tax rates). Richardson and Sawyer also examined the research on five further variables - four of which had been identified by Jackson and Milliron as potential research growth areas - compliance costs, tax preparers, framing and positive inducements - together with a fifth - tax amnesties - and again reported that progress had been mixed.

Perhaps this is not surprising given the range and complexity of factors that might affect compliance. To take a few more examples, tax morale might be important (Torgler 2007) as well as cultural influences (Coleman and Freeman 1997). The implications of different political systems have also been studied (Pommerehne, Hart and Frey 1994). More direct contributions to policy in this area have come from a number of authors. One is an appeal to taxpayers' conscience (Hasseldine and Kaplan 1992) and also to feelings of guilt and shame (Erard and Feinstein 1994). Others have suggested more positive help for taxpayers (Hite 1989) and different methods of achieving this - such as the use of television to change taxpayers' attitudes towards fairness and compliance (Roberts 1994) - or using different forms of written communications to improve compliance (Hasseldine et al. 2007). It is also possible that taxpayers consider the benefits the community receives from government expenditures (Falkinger 1988). There may therefore be scope to improve compliance by drawing attention to the benefits of public spending. Many more papers of this nature could have been cited and, depending on how they are classified, it is clear that there are over 20 variables linked with noncompliance. The issue of tax compliance therefore indicates that economic factors narrowly defined, although very important, are insufficient on their own to understand taxpayer behavior fully and it is necessary to take account of other important variables in developing tax policy. Similar considerations apply to the other example examined in this paper - tax simplification.

\section{TAX SIMPLIFICATION}

Tax simplification is also a complex issue (see, for example, James 2007) and provides a second example of the dangers of not taking appropriate account of the wider context in developing tax policy. As already indicated, there was an early and very striking example with a paper entitled 'Tax Simplification' in the Accounting Review which put a great deal of emphasis on reducing the pages of tax law. This seems to discount the importance of all the functions and features of a tax system, other than that it should be a simple one. There have been authors who have recognized that factors in addition to simplification are important in achieving the aims of the tax system. For example, Kaplow (1996) described a relatively simple framework that incorporated equity and efficiency matters with complexity and compliance. There are powerful pressures towards increasing the complexity of a tax system to address concerns over both horizontal and vertical equity, to take account of the increasing complexity of modern economies, and to enable governments to pursue their various economic and social policies. The optimal level of simplicity is therefore a very complex matter and will change according to current policy priorities and circumstances. However, there has also been a tendency in this area, when it is considered at all, for some to overestimate the importance of just this one aspect of the tax system and one of the most vivid examples is the view that the solution to the problem of complexity in the tax system is largely a matter of simplifying tax law. 


\section{Tax Law Reviews}

In Australia, New Zealand and the UK a response to these issues has been a number of attempts to rewrite the tax law in a simpler form. In the UK the Tax Law Review Committee was set up in 1994 to rewrite tax legislation in plain English and examine explanatory documentation. In Australia the process began with a report produced by the Joint Committee of Public Accounts in 1993. The Tax Law Improvement Project (TLIP) was then set up with the task of improving the 'understanding of the law, its expression and its readability' (Tax Law Review Team 1994). There is no doubt that improvements have been made, though such attempts have not always been well received. For example, in Australia Lehmann (1995) referred to some of the rewritten law as 'kindergarten babble' and cited the inclusion of 'Your assessable income includes income according to ordinary concepts, which is called ordinary income'.

There does seem to have been a view at the time that the tax law rewrites were the solution to the problem of excessive complexity but, certainly on their own, they are not. An initial part of the Australian rewrite duly appeared as the Income Tax Act 1997. In reviewing the position, Krever (2003) pointed out that a superficial look at that Act seemed to support the view that the complexity of the system was the fault of the drafters of earlier legislation. However, he went on to say that taxpayers and their advisers soon discovered that, although the new legislation was easier to read and comprehend than what had gone before, the complexity was still there. In fact the process had exposed the true cause of the previous law's complexity - that is its 'wholly irrational and inconsistent policy base' ( $p$. 493). Furthermore, TLIP seemed to have distracted attention from the normal process of revising tax legislation outside the project where problems continued and might even have increased. In New Zealand, Sawyer (2007) found that the tax law rewrite program had made marginal progress but it was too early to conclude if it would eventually be a success or failure. In the UK, the Tax Law Review Committee's final report (1996) listed three types of complexity - linguistic, policy and compliance - and acknowledged that a comprehensive tax reform would have to address all three areas (paragraph 6.10). The Committee also stated that 'without policy changes the benefits from rewriting legislation are limited' (paragraph 12). There is little doubt that communications between revenue agencies and taxpayers is more complex than simplifying language alone (James, Lewis and Allison 1987). A recent Australian contribution has been the Taylor Report (2006) on reducing tax law complexity. The principal conclusion of the Report was that the fundamental principles the tax law was trying to express were obscured by excessively detailed operational rules and it made a number of recommendations for improvement.

Although initiatives such as those for tax law improvement are to be welcomed, in both Australia and the UK they have been limited in that they were concerned with only part of the problem, complexity of language, and sometimes that is only a small part of the problem. These initiatives made no serious attempt to address the underlying complexity of the tax system and the process of tax reform generally from which such complexity arises (James and Edwards 2007). The experience in Australia, Canada, New Zealand and the UK was summed up by Owens and Hamilton (2004, p. 350) - that without simplifying the underlying tax policy it is not possible to simplify the tax law. Furthermore, trying to do so neglects 
the possibility that other aims and realities of the tax system might be more important than simplification.

A simple tax system cannot be used with any great degree of discrimination to support different government policies, such as those involving the encouragement of some activities and the discouragement of others. In terms of fairness there is clear evidence that taxpayers can have a very strong preference for a fair tax rather than a simple one. The UK provided a notable natural experiment on this issue in reforming local taxation. Instead of introducing a local income tax based on ability to pay, the community charge, or the poll tax as it was widely known, replaced local authority rates in Scotland in 1989 and England and Wales in 1990 (Smith 1991). The community charge met all but one of the economic criteria of a good tax - efficiency, incentives etc. and also the three main criteria for a good local tax - it had a potentially large tax base, the rates could be adjusted locally and, if local administrative areas are considered to be population groups rather than geographical areas, the tax base was relatively well distributed. In terms of basic principles it failed only on the criteria of equity but this was sufficient to generate considerable taxpayer resistance and even civil disturbance. Indeed the unfairness of the tax made it a contributory factor in the events leading to the resignation of Mrs Margaret Thatcher as Prime Minister and it was in turn replaced by the council tax in 1993 (James and Nobes 2006).

In addition, the poll tax also provided one of many notable examples (for others see James and Edwards 2007) of ad hoc tax policy-making that failed to achieve its aims. Simplification also provides an example of an issue that is often neglected but then becomes the focus of a temporary burst of attention as in the tax law rewrite programmes. Sometimes the need to address the issue on an ongoing basis is recognized - in the UK for instance, the Inland Revenue (1995) has discussed the creation of a simplification 'culture' within the Revenue that it is important to maintain and encourage. However, even this would be insufficient to achieve simplification successfully on its own and some other researchers have also come to the view that a broader approach is needed. For instance, after comparing progress in the USA, Australia, New Zealand and the UK, McKercher, Meyer and Starlinsky (2007, p. 359) concluded that little (if any) progress could be made towards tax simplification even if there appears to be real commitment by policy-makers, unless there is a clear understanding of the process and requirements of tax simplification and, in particular, 'the fundamental necessity to begin by developing appropriate tax policy in the broader context of economic reform'. What is needed is for these and other issues to be incorporated in tax policy-making in an appropriate and consistent manner and on a continuing basis.

As in the case of compliance, the approach should be a much wider one, incorporating all relevant issues and taking account of the important relationships between different policy aims, different variables and different outcomes. As already mentioned Kaplow (1996) developed a framework for a more unified analysis of tax complexity together with equity and efficiency concerns found in much tax policy formulation. However, as Kaplow pointed out, the framework is a simple one and the issues involved are complex. Therefore there seems to be a need to provide a link between all relevant factors, including academic research, and the formulation of tax policy and it is to that area the paper now turns. 


\section{DEVELOPING TAX POLICY IN A COMPLEX AND CHANGING WORLD}

As already indicated, successful tax reform can be a surprisingly complex process (see for example Bird 2004) and, as pointed out by Owens (2006) in his analysis of tax reform in 30 OECD countries, it is a continuing process with tax policy makers and tax administrators constantly adapting their tax systems to take account of changing economic, social and political circumstances. However experience shows that it is very difficult to achieve and maintain an ideal tax system. For example, the (US) President's Advisory Panel on Federal Income Tax Reform (2005, p. 1) stated that:

'If you were to start from scratch, the current tax code would provide a guide on what to avoid in designing an income tax system'.

Furthermore, instead of clarity there was opacity, instead of simplicity there was complexity, instead of fair principles there appeared to be arbitrary rules, instead of promoting economic growth it was an obstacle to growth. In the UK the Tax Reform Commission (2006) found that the UK tax system was too complex, too unfair, too unstable and undermined economic growth and similar assessments can also be found regarding other contemporary tax systems.

One way of taking account of the many different factors affecting tax policy is to develop a strategy for improvements and earlier attempts have been made in the case of compliance (James 2005) and simplification (James and Wallschutzky 1997). In both cases the emphasis was that the approach should not be on an ad hoc basis but in the form of a strategy that takes account of the different factors involved and the best ways of responding over time to particular issues in the context of the tax system as a whole. Such an approach might also improve the applicability of tax research more generally.

The academic discipline that has paid most attention to the subject of developing strategy is Management. An essential input in the development of successful strategies is the systematic analysis and understanding of the factors involved. This includes the wider environment in which the activity is being conducted as well as the areas of immediate concern - which can easily be done in the case of taxation (James 1999). A key part in the development of strategy is implementation. Mintzberg (2004, p. 55) is one of the most prominent management scholars in the area and believes that strategy is an interactive process requiring constant feedback between thought and action and that successful strategies evolve from experience. He also stresses the importance of strategists having expertise in the area and that they should not simply pontificate at a high level of abstraction and leave it to others to implement the strategies (and certainly not blame them for any shortcomings in the strategy). Other commentators such as Grant (2002) are also clear that the formulation and implementation of strategy go together. A well-designed strategy should take account of the process of implementation and it is through the implementation that a strategy can be refined and reformulated.

The present authors developed such an approach with respect to income tax in an Australian context (James and Edwards 2007) but a more general approach can also be summarized here. There are certain distinct stages in developing such a strategic approach and one possible ten stage plan consists of: 
1. Identify the aims of taxation

2. Establish different methods of achieving the aims

3. Analyse in terms of economic criteria.

4. Specify the administrative constraints

5. Identify different risks.

6. Analyse behaviour

7. Consider the relationship between different policies

8. Develop strategies

9. Plan and implement strategies including intended outcomes

10. Monitor and evaluate the performance of the strategies against the plan

These can each be considered a little further as follows:

\section{Identify the Aims of Taxation}

Taxation, of course, is used not only to raise revenue but also as an instrument for achieving a range of government economic and social policies. This includes the redistribution of income as well as encouraging some activities and discouraging others. The relative importance of all these different aims and objectives should be considered in deciding on particular features of the tax system including policies relating to compliance and simplification.

\section{Identify Different Methods of Achieving the Aims}

Taxation might be the best way of achieving the objectives but it may not. For example, tax expenditure describes the method of conferring some fiscal advantage on a particular group or particular activity by reducing tax liability rather than by a direct tax subsidy. This might be wholly unsuitable for some purposes - for example redistributing income - since the benefit depends on a person's marginal rate of tax. Those subject to the highest rate of tax will receive the greatest individual benefit from an income tax concession and someone too poor to pay income tax will not receive any benefit at all. Tax expenditures complicate the tax system and may introduce perverse incentives to those not intended to benefit from them. Aaron and Galper (1985) argue that using taxation to promote worthy causes is usually unfair and inefficient. The original aims might be better achieved by the use of non-tax methods or possibly some combination of tax and non-tax methods.

\section{Analyse in Terms of the Economic Criteria}

The main economic criteria that may be used to analyse different reforms are efficiency, incentives, equity, incidence and macroeconomic considerations. These are described at much greater length elsewhere (James and Nobes 2006) but basically the efficiency question is how a tax might affect the efficiency of the economy through effects on the allocation of resources and also the extent and nature of compliance and administrative costs. Incentives are part of this analysis but sufficiently important to justify a separate examination of the likely effects on the willingness to work, save and invest. Equity issues are particularly important since taxes that are not considered fair by taxpayers are much more difficult, and sometimes impossible, 
to operate successfully. The analysis of tax incidence will indicate who is likely to be affected by taxes through changes in prices and other economic variables. A tax on one good or service might increase its price and reduce demand and this will cause changes in the pattern of consumption which will affect the demand and prices of other goods and services, even if they are not subject to this particular tax directly. The inputs to both taxed and untaxed goods and services may also be affected. Tax capitalization is often overlooked but should not be - it describes the effect of the market price of an asset when a tax influences the expected yield of that asset. Finally, macroeconomic considerations might also be important for large changes. A particular reform might have implications for the level of unemployment and inflation.

\section{Specify the Administrative Constraints}

Given the copious writing on tax reform, there is little evidence that the importance of tax administration has been taken seriously enough (see, for example, Bird 1998) and this is particularly important in relation to issues relating to both compliance and simplification. Administrative issues can influence the whole nature of a particular tax reform and be the deciding factor in its success or failure. It is often a binding constraint on what can be done. For instance some strategies may not be popular with taxpayers to the extent that they are not viable. There may be legal aspects, including obligations under international arrangements, which should be taken into account. Furthermore, all strategies are subject to overall resource limitations including the staff resources and skills of the revenue agency and it may have changing priorities with respect to the use of these scarce resources.

\section{Identify Different Risks}

As Owens (2006, p. 160) points out, with a constantly changing tax environment, it is dangerous to assume that the future will just be a continuation of the past. To establish the areas of significant risk a multilevel approach is needed. At the top level, an assessment is needed of the tax environment and relevant aspects. James (1999) used a strategic management approach for assessing the political, economic, social and technological factors that affect the tax environment and international tax trends and such an approach can be used to identify areas of risk and changes to risk.

\section{Analyze Behavior}

It is important to take account of likely behavior with respect to taxation and a great deal of work has been done in this area as indicated in Section 3 above. Such behavioral factors can mean, for example, that some taxes are relatively acceptable and therefore relatively easy to administer while others encounter much greater taxpayer resistance of various sorts and are therefore more difficult to operate successfully.

\section{Relationship with Different Policies}

The next step is to take account of the relationship of the tax system to broader government economic and social policies. It might be that different policies are not always compatible 
and there may be, for instance, a trade-off between the need to raise revenue and the need to keep tax rates low to promote economic incentives. It is often not possible to reform taxation without changing other aspects of government activity as well.

\section{Develop Strategies}

Given the different aspects of the subject, strategies should be both comprehensive enough to address general issues and sufficiently flexible to focus on areas of particular concern. The strategies should take account of the areas of highest priority and those where there is the highest probability of success.

\section{Plan and Implement Strategies Including Intended Outcomes}

There are several general considerations involved in planning and implementing strategies. As indicated above, one is to ensure that the planning in this area is consistent with the overall activities of the revenue agency and that resources are used in an efficient and effective way. It is important to gain the support of stakeholders and this can be done in a number of ways such as involving them in the planning stage and providing explanations with respect to the intended strategy. It is important that the plan should include intended outcomes and a mechanism for monitoring and evaluating the strategies. Where possible the relevant variables should be quantifiable but not everything in this area can be measured so qualitative feedback should also be sought. Finally there must be provision for modifying the strategies in the light of their performance in practice as well as to take account of changing circumstances.

\section{Monitor and Evaluate the Performance of the Strategies Against the Plan}

Monitoring and evaluating performance, of course, is not always an easy task. However a number of issues are worth mentioning. Given the complexity of the tax administration process, one single indicator is unlikely to be sufficient to monitor the whole situation. Observing the trends in particular outcomes is a useful exercise but care should also be taken to continue to monitor the changing situation with regard to the tax environment and practice, particularly taxpayer behaviour. Over time different issues may well change in their importance with respect to the overall strategy and new ones might emerge.

The final stage in this process is to use the results of the monitoring and evaluation of performance to feed back into the continuous development of the most appropriate tax strategies.

\section{CONCLUSIONS}

The formulation of successful tax reform starting from the identification of possible improvements through developing, implementing and monitoring actual changes is a difficult and complex process. As demonstrated in this paper, if tax reform does not take account of relevant factors, the advantages of particular changes to governments and the taxpayers they represent might be outweighed by disadvantages that were not anticipated. Furthermore, some tax research might take insufficient account of the wider context of the subject of study in developing 
conclusions. The aims of policy-makers are often multi-dimensional and their priorities can change over time and even, occasionally, quite quickly. It is clear that a change to one part of the system can affect the operation of other parts and the whole process has to take place in a complex and changing economic, social, and political environment. This paper has concentrated on the two issues of tax compliance and tax simplification. A policy to minimize compliance costs, or to close the tax gap or to simplify the tax system without sufficient regard to other matters may not improve matters overall. For instance, a policy of minimizing compliance costs overlooks the possibility that other factors might be more important - that there may be a trade-off between compliance costs and other policy objectives. These matters are so complex that, at least in terms of present knowledge, it seems impossible to derive any meaningful measure of the optimum level of compliance costs that would have any useful practical policy application. Similarly, the work on simplifying tax law in a number of countries does not seem to have achieved a great deal in terms of tax simplification and is unlikely to do so unless such reforms take account of all aspects of the issue. Again, like compliance, tax simplification is not an independent aim of taxation - the most appropriate degree of simplicity in a tax system depends on all the other issues raised in this paper. In developing tax policy it is important that tax researchers and tax policy-makers take account of the range of aims and objectives of the tax system and the environment in which it has to operate. The previous section therefore offers a practical approach to the development of tax policy that allows all the relevant factors to be considered on a systematic and continuing basis.

\section{REFERENCES}

Aaron, H. and H. Galpher (1985). Assessing Tax Reform. Washington DC: Brookings Institution.

Ahmed, E., J. McCrae, V. Braithwaite, and Y. Sakurai (2003). Bringing It Together (BIT), Vol.1; An Annotated Bibliography Relating to Voluntary Tax Compliance. http://ctsi.anu.edu.au/publications/ taxpubs/annotated.bibiography.pdf, accessed July 20, 2005.

Alm, J. (1996). What is an 'Optimal' Tax System?, National Tax Journal. 49: 117-133.

Alm, J., G. H. McClelland, and W. D. Schulze (1999). Changing the Social Norm of Tax Compliance by Voting, Kyklos. 52: 141-171.

Bachrach, M. D. (1945). Tax Simplification, Accounting Review. 20: 102-103.

Balestrino, A. and U. Gallmarini (2003). Imperfect Tax Compliance and the Optimal Provision of Public Goods, Bulletin of Economic Research. 55: 37-52.

Bird, R. M. (1998). Administrative Constraints on Tax Policy, in: C. Sandford (ed.), (1998), Further

Key Issues in Tax Reform. Bath: Fiscal Publications.

Bird, R. M. (2004). Managing Tax Reform, Bulletin for International Fiscal Documentation. 58: 42-55.

Bordington, M (1993). A Fairness Approach to Income Tax Evasion, Journal of Public Economics. 52: 345-362.

Braithwaite, V. (ed.) (2003). Taxing Democracy: Understanding Tax Avoidance and Evasion, Aldershot: Ashgate.

Broome, J. (1975). An Important Theorem on Income Tax, Review of Economic Studies. 42: 649-652.

Chang, J. J. and C. C. Lai (2004). Collaborative Tax Evasion and Social Norms: Why Deterrence Does Not Work, Oxford Economic Papers. 56: 344-368.

Coleman, C. and L. Freeman (1997). Cultural Foundations ofTaxpayerAttitudes to Voluntary Compliance, Australian Tax Forum. 13: 311-336.

Cowell, F. A. (1992). Tax Evasion and Equity, Journal of Economic Psychology. 13: 521-543.

Cremer, H. and F. Gahvari (1994). Tax Evasion, Concealment and the Optimal Linear Income Tax, Scandinavian Journal of Economics. 96: 219-239. 
Cullis, J. G. and A, Lewis (1997). Why People Pay Taxes: from a Conventional Economic Model to a Model of Social Convention, Journal of Economic Psychology. 18: 305-321.

Erard, B. and J. S. Feinstein (1994). The Role of Moral Sentiments and Audit Perceptions in Tax Compliance, supplement to Public Finance. 49: 70-89.

Falkinger, J. (1988). Tax Evasion and Equity: A Theoretical Analysis, Public Finance. 43: 388-395.

Feldstein, M. S. (1977). On the Theory of Tax Reform, Journal of Public Economics. 6: 77-104.

Fischer, C. M., M. Watrick, and M. M. Mark (1992). Detection Probability and Taxpayer Compliance: A Review of the Literature, Journal of Accounting Literature. 11: 1-46.

Frey, B.S. (1976). Taxation in Fiscal Exchange - A Comment, Journal of Public Economics. 6: 31-35.

Gradstein, M. (1999). Optimal Taxation and Fiscal Constitution, Journal of Public Economics. 72: 471-485.

Grant, R. M. (2002). Contemporary Strategy Analysis: Concepts, Techniques, Applications. $4^{\text {th }}$ ed. Oxford: Blackwell.

Hasseldine, J., P. Hite, S. James and M. Toumi (2007). Persuasive Communications: Tax Compliance Enforcement Strategies for Sole Proprietors, Contemporary Accounting Research. 24: 171-194.

Hasseldine, J., and S. E. Kaplan (1992). The Effect of Different Sanction Communications on Hypothetical Taxpayer Compliance: Policy Implications from New Zealand, Public Finance. 47: 45-60.

Heady, C. (1993). Optimal Taxation as a Guide to Tax Policy: A Survey, Fiscal Studies. 14: 15-41.

Herrnstein, R. J., G. F. Loewenstein, D. Prelec, and W. Vaughan Jr. (1993). Utility Maximization and Melioration: Internalities in Individual Choice, Journal of Behavioral Decision Making. 6: 149185.

Hite, P.A. (1989). A Positive Approach to Taxpayer Compliance, Public Finance. 44: 249-266.

Inland Revenue (1995). The Path to Tax Simplification: A Background Paper. London: Her Majesty's Stationery Office.

Jackson, B. and V. C. Milliron (1986). Tax Compliance Research: Findings, Problems and Prospects, Journal of Accounting Literature. 5: 125-165.

James, S. (1999). The Future International Tax Environment and European Tax Harmonization: A Personal View, European Accounting Review. 8: 731-747.

James, S. (2005). Tax Compliance Strategies to Tackle the Underground Economy, in: C. Bajada and F. Schneider (eds.), (2005), The Size Cause and Consequences of the Underground Economy: An International Perspective. Aldershot: Ashgate: 275-289.

James, S. (2007). Tax Simplification is Not a Simple Issue: The Reasons for Difficulty and a Possible Strategy. University of Exeter Discussion papers in Management, $\mathrm{n}^{\circ} 07 / 18 \mathrm{http} / / \mathrm{www}$.sobe.ex.ac. uk/research/management/discussion_papers/index.php?id=366

James, S. and A. Edwards (2007). A Strategic Approach to Personal Tax Reform, Australian Tax Forum. 22: $105-126$.

James, S., J. Hasseldine, P. Hite, and M. Toumi (2001). Developing a Tax Compliance Strategy for Revenue Services, Bulletin for International Fiscal Documentation. 55: 158-164.

James, S., A. Lewis, and F. Allison (1987). The Comprehensibility of Taxation: A Study of Taxation and Communications. Aldershot: Avebury.

James, S., and C. Nobes (2006). The Economics of Taxation: Principles, Policy and Practice, $7^{\text {th }}$ edition revised. Harlow: Prentice Hall.

James, S., and I. Wallschutzky (1997). Tax Law Improvement in Australia and the UK: The Need for a Strategy for Simplification, Fiscal Studies. 18: 445-460.

Kaplow, L. (1996). How Tax Complexity and Enforcement Affect the Equity and Efficiency of the Income Tax, National Tax Journal. 49: 135-50.

Kirchler, E. (2007). The Economic Psychology of Tax Behaviour. Cambridge: Cambridge University Press.

Krever, R. (2003). Taming Complexity in Australian Income Tax. Sydney Law Review. 25: 467-505.

Lehmann, G. (1995). The Reform that does not Reform and the Simplification that Does Not SimplifyThe Tax Law Improvement Project Fiasco, Butterworth's Weekly Tax Bulletin. 33: 530-33. 
Lewis, A. (1982). The Psychology of Taxation. Oxford: Blackwell.

Lipsey, R. G. and K. Lancaster (1956). The General Theory of the Second Best, Review of Economic Studies. 24: 11-32.

McKerchar, M., Meyer and S. Karlinsky (2007). Making Progress in Tax Simplification: A Comparison of the United States, Australia and the United Kingdom, in: M. McKerchar and M. Walpole (eds.), (2007), Further Global Challenges in Tax Administration, Birmingham: Fiscal Publications: 159-173.

Mintzberg, H. (2004). Managers Not MBAs: A Hard Look at the Soft Practice of Managing and Management Development. San Francisco: Berret-Koehler, Publishers.

Musgrave, R. A. (1959). The Theory of Public Finance. New York: McGraw Hill.

O’Donoghue, T. and M. Rabin (2006). Optimal Sin Taxes, Journal of Public Economics. 90: 18251849.

Owens, J. (2006). Fundamental Tax Reform: An International Perspective, National Tax Journal. 59: 131-164.

Owens, J. and S. Hamilton (2004). Experience and Innovations in Other Countries, in: H. J. Aaron and J. Slemrod (eds.), (2004). The Crisis in Tax Administration. Washington DC: Brooking Institution Press: $347-379$.

Pommerehne, W. W., A. Hart, and B. S. Frey (1994). Tax Morale, Tax Evasion and the Choice of Policy Instruments in Different Political Systems, supplement to Public Finance. 49: 52-69.

President's Advisory Panel on Federal Tax Reform (2005), Simple, Fair and Pro-Growth: Proposals to FixAmerica's Tax System, November. http://www.taxreformpanel.gov/final-report/TaxReform_Ch1. pdf, accessed 25 February 2007.

Ramsey, F. P. (1927). A Contribution to the Theory of Taxation, Economic Journal. 37: 47-61.

Richardson, R. M. and A. Sawyer (2001). A Taxonomy of Tax Compliance Literature: Further Findings, Problems and Prospects, Australian Tax Forum. 16: 137-320.

Roberts, M. L. (1994). An Experimental Approach to Changing Taxpayers' Attitudes Towards Fairness and Compliance via Television, Journal of the American Taxation Association. 16: 67-86.

Sabine, B. (1965). A History of Income Tax. London: Allen and Unwin.

Sandford, C., M. Godwin, and Hardwick (1989). Administrative and Compliance Costs of Taxation. Bath: Fiscal Publications.

Sandmo, A. (2005). The Theory of Tax Evasion: A Retrospective View, National Tax Journal. 53: 643-663.

Sawyer, A. (2007). New Zealand's Tax Rewrite Programme - In Pursuit of the (Elusive) Goal of Simplicity, British Tax Review. 1: 405-427.

Schmölders, G. (1959). Fiscal Psychology: A New Branch of Public Finance, National Tax Journal. 15: 184-193

Schmölders, G. (1970). Survey Research in Public Finance: A Behavioural Approach to Fiscal Theory, Public Finance. 25: 300-306.

Serra, P. (2003). Measuring the Performance of Chile's Tax Administration, National Tax Journal. 56: 373-383.

Sheikdele, C. (2001). Report of a Study on Measuring the Compliance Costs of Taxation: Excise Duties 1995-96, Dar es Salaam, Institute of Finance Management. Available on the web: http://pdf.dec. org/pdf_docs/PNACM655.pdf, accessed March 7, 2007.

Smith, P. (1991). Lessons from the British Poll Tax Disaster, National Tax Journal. 44: 421-436.

Spicer, M. W. (1986). Civilization at a Discount; The Problem of Tax Evasion, National Tax Journal. 39: $13-20$.

Strümpel, B. (1969). The Contribution of Survey Research to Public Finance, in: A. T. Peacock (ed.), (1969), Quantitative Analysis in Public Finance. New York: Praeger: 13-32.

Taylor, C. J. (2006). Beyond 4100: A report on measures to combat rising compliance costs through reducing tax law complexity. Sydney: Taxation Institute of Australia.

Tax Law Review Committee (1996). Final Report on Tax Legislation. London: Institute for Fiscal Studies. 
Tax Law Review Team (1994). The Broad Framework. Canberra: Australian Tax Office.

Tax Reform Commission (2006), Tax Matters: Reforming the Tax System, Report of the Tax Reform Commission, http://www.taxreformcommission.com/.

Torgler, B. (2007). Tax Compliance and Tax Morale: A Theoretical and Empirical Analysis. Cheltenham, UK: Edward Elgar.

Turner, J. (1996). A Critical Analysis of Australian Taxation Compliance Costs Research, Master of Commerce Research Project, University of South Australia.

Wenzel, M. (2004a). An Analysis of Norm Processes in Tax Compliance, Journal of Economic Psychology. 25: 213-218.

Wenzel, M. (2004b). The Social Side of Sanctions: Personal and Social Norms as Moderators of Deterrence, Law and Human Behaviour. 28: 547-567.

Wenzel, M. (2005). Misperception of Social Norms about Tax Compliance: From Theory to Intervention, Journal of Economic Psychology. 26: 862-883.

West S. E. and R. C. Williams III (2007). Optimal Taxation and Cross-price Effects on Labor Supply: Estimates of the Optimal Gas Tax, Journal of Public Economics. 91: 593-617. 
